\title{
Study of the Making of Hydrolizate Protein Powder of Rebon Shrimp as a Food Nutrition Enhancement Ingredient
}

\author{
Suparmi ${ }^{1, *}$, Dewita ${ }^{1}$, Desmelati ${ }^{1}$, Taufik Hidayat ${ }^{2}$
}

Suparmi ${ }^{1, *}$, Dewita $^{1}$, Desmelati ${ }^{1}$, Taufik Hidayat $^{2}$

'Department of Aquatic Product Technology, Faculty of Fisheries and Marine Science, University of Riau, INDONESIA.

${ }^{2}$ Agency for Assesment and Aplication of Technology, Laptiab Building Puspiptek Serpong, INDONESIA

\section{Correspondence}

Suparmi

Department of Aquatic Product Technology,

Faculty of Fisheries and Marine Science,

University of Riau, INDONESIA.

E-mail: teten_58@yahoo.co.id

History

- Submission Date: 08-06-2021;

- Review completed: 28-06-2021;

- Accepted Date: 07-07-2021.

DOI : 10.5530/pj.2021.13.151

Article Available online

http://www.phcogj.com/v13/i5

Copyright

(C) 2021 Phcogj.Com. This is an openaccess article distributed under the terms of the Creative Commons Attribution 4.0 International license.

\section{ABSTRACT}

Rebon shrimp protein hydrolyzate has the potential to be used as a protein powder as a nutritional supplement. The aim of this study was to determine the best protein hydrolyzate concentration as a raw material for protein powder. The research was carried out in two stages, each of which was related. The first stage was made of protein hydrolyzate using 2 treatments, namely enzymatic hydrolysis $(15 \%$ papain) and fermentation using 10\% L plantarum bacteria. The parameters observed included yield, amino acid profile and fatty acid profile. The second stage was determining the best concentration of 5 level $(6 \%$ $7 \%, 8 \%, 9 \%$ ) protein hydrolyzate, as a binder was added gum arabic and dextrin (1: 0.5) the amount of $8 \%(\mathrm{w} / \mathrm{v})$. observed parameters, organoleptic values, physical characteristics and degree of brightness. The results of this research can be concluded that the hydrolyzate of rebon shrimp protein with the best concentration is $9 \%$. can be used as a protein powder as a nutritional supplement with the addition of gum arabic binder and dextrin (1: 0.5) with a yield value of $73.191 \%$ and a total amino acid of $46.70 \%$. The content of fatty acids produced The fatty acids contained are mMyristic acid $0.264 \%$, palmintic acid $6.361 \%$, stearic acid $0.678 \%$, oleic acid $16.704 \%$ (Omega 9) and linoleic acid $0.084 \%$ (Omega 6). Organoleptic value of protein powder, namely taste 8.6, aroma 8.4, appearance 8.8, texture 8.5, with the characteristics of a bright yellowish white color, not fishy aroma, fine texture and very savory taste (umami), the brightness value at the level of $97.82 \%$

Key words: Acetes erythreaeus, Dextrin, Gum arabic, Hydrolyzate, L plantarum sp.

\section{INTRODUCTION}

Rebon shrimp is rich in protein which can be used as raw material for protein hydrolyzate whose protein content consists of both essential and nonessential amino acids where the function of the protein is for the human body to maintain health, Utilization of rebon shrimp as a protein source can be done by making protein hydrolyzates.

Rebon shrimp protein hydrolyzate in liquid form has a weakness, which is more easily contaminated and easily damaged due to high water content. But with the method of adding protein binders, it can be made in powder form, so it is not easily contaminated and easy to store because it has low water content and has high solubility so that it is easy to add to food ingredients to be supplemented.

In the process of making powder from a liquid, a binding agent is needed and the materials that can be used are gum arabic and dextrin. Arabic gum can act as an elmusifier and dissolves easily in water and in oil ${ }^{1}$, while dextrins have stable molecules so they can protect compounds that are sensitive to oxidation and heat ${ }^{2}$.

It is hoped that the production of rebon shrimp protein hydrolyzate powder will be able to produce supplement materials that have high protein. So, the purpose of this study was to determine the best concentration of rebon shrimp protein hydrolyzate which was powdered as an ingredient in nutritional supplementation.

\section{MATERIALS AND METHODS}

\section{Materials and tools}

The raw materials used in this study were fresh rebon shrimp, papain enzymes and $L$ plantarum sp. Bacteria. The binding agents used were gum arabic and dextrin. Other materials used are Glucose, $\mathrm{NaOH}$ (Merck), 85\% alcohol, $\mathrm{HCl}$ (Merck), $\mathrm{NaCl}$ (Merck), and phosphate buffers (Merck) and $\mathrm{NaOH}$. Chemicals used for amino acid analysis. The main tools used in this research are an incubator (IS900 Yamoto), autoclave (SM52), centrifuge (himac CR 21G), homogenizer (Nissel AMS), oven draying (SH62), freeze dryer, Spectrophotometer (Shimadzu 120-01), HPLC, Magnetic stirer, Oven, stainless steel blender, $\mathrm{pH}$ meter (HM-205), Vortek, and Water bath (GFL1083), refrigerator, analytical scale, glassware, spatula, distillation, biuret and film bottle, 60 mesh sieve.

\section{Research methods}

The research process was carried out in two stages. The first stage aimed to obtain the best protein hydrolyzate from the two treatments, namely enzymatically and microbiologically. The parameters analyzed were yield, amino acid profile, and fatty acid. The second stage aims to determine the best concentration of 5 treatment levels $(6 \%, 7 \%, 8 \%, 9 \%)$ protein hydrolyzate as a raw material for nutritional supplement powder as a protein binding agent, added with Arabic gum and dextrin (1:0.5) 8\%, the parameters observed were moisture content, fungi, physical characteristics, organoleptic values, and degree of brightness.

Cite this article: Suparmi, Dewita, Desmelati, Hidayat T. Study of the Making of Hydrolizate Protein Powder of Rebon Shrimp as a Food Nutrition Enhancement Ingredient. Pharmacogn J. 2021;13(5): 1180-1185. 


\section{Procedure for Making Rebon Shrimp Protein Hydrolyzate ${ }^{3}$}

Fresh rebon shrimp as much as $500 \mathrm{~g}$ are cleaned and washed with running water, then crushed, then added $500 \mathrm{ml}$ of sterile water (1: 1 $\mathrm{w} / \mathrm{v})$ then homogenized, then heated at $60{ }^{\circ} \mathrm{C}$ for 15 minutes aims to activate the shrimp enzyme. The optimum $\mathrm{pH}$ adjustment was carried out using $0.5 \mathrm{~N} \mathrm{NaOH}$ to reach $\mathrm{pH} 7$, added the papain enzyme with a concentration of $15 \%$ of the weight of the shrimp, then incubated at 60 ${ }^{\circ} \mathrm{C}$ for 4 hours, after heating using a water bath at $85{ }^{\circ} \mathrm{C}$ for 15 minutes, to separate the liquid phase and the solid phase, centrifugation was carried out at a speed of $15000 \mathrm{~g}$ for 15 minutes. The supernatant obtained was protein hydrolyzate of rebon shrimp.

\section{Procedure for making rebon shrimp protein hydrolyzate} using L. plantarum sp. ${ }^{4}$

Fresh rebon shrimp as much as $500 \mathrm{~g}$ are cleaned and washed with running water, then crushed using a blender then added $1: 1(\mathrm{w} / \mathrm{v})$ sterile water then homogenizer is sterilized at $121^{\circ} \mathrm{C}$ for 15 minutes, after which $1 \%$ sterile glucose is added. (b / v). Then add $10 \% L$ plantarum sp., Then put it in a glass bottle, ferment it for 96 hours. The fermentation process was stopped by heating it at $95^{\circ} \mathrm{C}$ for 15 minutes. To separate the liquid phase and the solid phase, centrifugation was carried out at a speed of $10,000 \mathrm{~g}$ for 20 minutes. The supernatant obtained was protein hydrolyzate of rebon shrimp.

\section{Preparation of Protein Hydrolyzate Powder}

The second stage of the research was to make protein hydrolyzate powder, the treatment was to select the protein hydrolyzate concentration of rebon shrimp with a treatment interval of $6 \% ; 7 \%$; $8 \% ; 9 \%$. The step, then for each treatment was added a binder, namely a mixture of gum arabic and dextrin with a ratio of $1: 0.5$ with a total of $8 \%$, homogenizer then carried out the drying process with a spray dryer at an inlet temperature of $165^{\circ} \mathrm{C}$, outlet temperature $70^{\circ} \mathrm{C}$.

\section{RESULTS AND DISCUSSION}

\section{Phase I}

\section{Yield}

The results of the first phase of research showed that there was a difference in the percentage of yield between hydrolysis using papain enzyme 15\% (A) and hydrolysis treatment using fermentation by bacteria $L$ plantarum $10 \%$ (B). The yield of rebon shrimp protein hydrolyzate can be seen in Table 1.

The yield of rebon shrimp protein hydrolyzate can be seen in Table 1 , the yield of treatment protein hydrolyzate (A) was 365.954 grams or $73.191 \%$ higher than the yield of treated protein hydrolyzate (B) which amounted to 287.446 grams or $57.489 \%$, the low yield of both treatments This is probably because the wet rebon shrimp is still in the form of a coarse collision, not in the form of finer powder. This causes the active substance content which can be hydrolyzed by the papain enzyme and also by the L plantarum bacteria only on the surface of small fractions, not in the form of a finer powder.

\section{Amino Acid Profile}

The results of the amino acid profile analysis showed that the amino acid content of each shrimp protein hydrolyzate was showed in Table 2 . The difference in amino acid content in rebon shrimp protein hydrolyzate could occur due to differences in processing ${ }^{5}$. The hydrolysis treatment using the $15 \%$ papain enzyme resulted in a higher number of amino acids $(46.70 \%)$ compared to the hydrolysis treatment using $10 \% \mathrm{~L}$ plantarum bacteria, which was $14.28 \%$, this was due to hydrolysis using the papain enzyme to release protein from the cell wall. perfectly so that it affects the amount of amino acid content. According to ${ }^{6}$,
Table 1: The yield of rebon shrimp protein hydrolysate.

\begin{tabular}{cccc}
\hline Component & Initial weight (g) & Final Weight (g) & Value (\%) \\
\hline A & 500 & 365.954 & 73,191 \\
B & 500 & 287.446 & 57.489 \\
\hline
\end{tabular}

Noted:

$A=$ Protein hydrolyzate using papain enzyme

$\mathrm{B}=$ Protein hydrolyzate using L. plantarum bacteria

Table 2: Amino acid content of Rebon shrimp protein hydrolyzate.

\begin{tabular}{lcc} 
& \multicolumn{2}{c}{ rProduct } \\
\cline { 2 - 3 } Amino Acids & Protein hydrolyzate & Protein hydrolyzate \\
\hline Aspartate acids & B (\%) \\
Glutamate acids & 4.25 & 1.52 \\
Serine & 8.47 & 2.06 \\
Histidine & 1.31 & 0.56 \\
Glisin e & 2.60 & 0.84 \\
Treonine & 2.14 & 0.77 \\
Arginine & 1.44 & 0.60 \\
Alanine & 2.78 & 0.70 \\
Tirosine & 2.73 & 0.52 \\
Metionine & 1.03 & 0.35 \\
Valine & 2.18 & 0.78 \\
Penilalanine & 2.98 & 0.56 \\
I-Leuosine & 1.78 & 1.78 \\
Leusine & 2.14 & 0.86 \\
Lisine & 3.28 & 1.30 \\
TOTAL & 3.93 & 1.08 \\
\hline
\end{tabular}

Noted:

$A=$ Protein hydrolyzate using papain enzyme

$\mathrm{B}=$ Protein hydrolyzate using L. plantarum bacteria

the papain enzyme is a proteolytic enzyme derived from papaya sap, this enzyme has the ability to break down protein molecules and can hydrolyze peptide bonds that build polypeptide chains on proteins to produce one molecule with carboxyl groups and other molecules that have amine groups. When enzymes are mixed in food, food protein will be broken down into peptides, which in turn break down into simpler forms called amino acids.

According to ${ }^{7}$, the function of protein hydrolyzate can be as a flavoring and to obtain individual amino acids or for treatment, namely as a diet for digestive sufferers. The low content of amino acids in the protein hydrolyzate treated using $10 \%$ L plantarum bacteria, this is due to the fermentation hydrolysis process in accordance with the opinion ${ }^{8}$, namely that when the fermentation process takes place, fish protein will be hydrolyzed into amino acids and peptides, then the amino acids will break down further into other components that play a role in the formation of taste. This opinion is further clarified by the results of ${ }^{9}$ research, namely that a longer fermentation process will lead to a reduction in the amino acid levels of the product.

\section{Fatty acids}

Other nutrients contained in the rebon shrimp protein didrolysate are the content of fatty acids, the amount can be seen in Table 3.Fatty acids contained in rebon shrimp proein hydrolyzate include saturated fatty acids (myristic acid, palminta and stearic acid), oleic acid (Omega -9) and linoleic acid (Omega-6), are a group of fatty acids that are needed for health, because according to ${ }^{10} ;{ }^{5}$; and ${ }^{11}$ state that omega 3,6 , and 9 fatty acids are that have a good effect on health, especially for brain growth, eye health, and according to ${ }^{12}$ that omega 3,6 and 9 fatty acids are found in many seafood, including shrimp. 
Based on the results in the phase 1 research, it can be concluded that hydrolysis using the $15 \%$ papain enzyme produces higher yields, amino acids and fatty acids than hydrolysis using the bacteria L.plantarum sp $10 \%$, so that the protein hydrolyzate produced from the enzymatic process is used as an ingredient. protein powder manufacturing standards in Phase II research.

\section{Phase II Research}

The second stage of the research was to make protein hydrolyzate powder, the treatment was to determine the protein hydrolyzate concentration of rebon shrimp with $6 \%$ intervals; $7 \% ; 8 \%$ and $9 \%$ then for each treatment a binder mixture of gum arabic and dextrin is added with a ratio of $1: 0.5$ for a total of $8 \%$, homogenizer then the drying process is carried out with a spray dryer at an inlet temperature of $165^{\circ} \mathrm{C}$, outlet temperature of $70^{\circ} \mathrm{C}$,

\section{Organoleptic Test}

The results of the organoleptic test for the protein hydrolyzate powder of rebon shrimp can be seen in Table 4 that the highest average value is related to taste, aroma, appearance and texture of protein hydrolyzate powder, namely at a concentration of $9 \%$ with a taste value (8.6), and aroma value $(8.4)$ visual value $(8,8)$, texture value $(8,5)$. Based on the results of the analysis of variance, it can be explained that the hydrolyzate concentration of rebon shrimp protein in different amounts has a significant effect on the organoleptic value. To see this difference, the Tukey test is continued, the results show that the $9 \%$ concentration is significantly different from the $6 \%$ concentration; $7 \%$; and $8 \%$.

Protein powder with a concentration of $9 \%$ is preferred by panelists, because the chemical content that gives the powder a savory taste, namely glutamic acid, the higher the concentration of adding rebon shrimp protein hydrolyzate causes the resulting taste and aroma to be stronger. According to ${ }^{13}$, that taste, aroma, appearance, and texture are parameters in determining product acceptance by consumers, the taste and delicacy of food is influenced by its chemical content.

The content of glutamic acid and aspartic acid in the protein hydrolyzate of rebon shrimp is $8.62 \%$ which can give a very savory taste to the functional flavor powder. According to ${ }^{14}$, high levels of glutamic acid and aspartic acid, amino acids and nucleotides can contribute to forming a savory taste (umami), forming monosodium glutamate salt and in general marine products have the type of amino glutamic acid. The percentage of glutamic acid content in food products is thought to be due to deamination between the amino acids glutamine and asparagine, thereby increasing glutamic acid levels in food products ${ }^{15}$.

\section{Physical Characteristics}

Based on the panelists' responses to the characteristics of protein powder from shrimp protein hydrolyzate, can be seen in Table 5 . Characteristics of protein powder with gum arabic and dextrin binder has a bright yellowish white color, the aroma is very real, the texture is dry, and smooth and the taste is very tasty.

\section{Degree of Brightness}

Assessment of the degree of color brightness was carried out using a Lutron 10 Bit Color Analyzer, RGB-1002 Type, the results obtained are stated in Table 6. The results of the analysis show a significant difference.

The assessment of the degree of brightness of the rebon shrimp protein hydrolyzate functional flavor powder produced (Table 6) showed that a difference in the degree of brightness where the functional flavor powder with $9 \%$ protein hydrolyzate concentration of rebon shrimp has high brightness, namely $97.82 \%$. The high degree of brightness of the powder means that the product has a good appearance and color, thereby creating an attraction for consumer acceptance. According to ${ }^{16}$, color is one of the main factors that are important in a food product. Because the first impression seen by consumers is when they see the

Table 3: Fatty Acid Content of Rebon Shrimp Protein Hydrolysate Powder.

\begin{tabular}{lcc}
\hline & & Product \\
\cline { 2 - 3 } Component & A(\%) & B (\%) \\
\hline Miristate acids & 0.264 & 0.223 \\
Palmintate acids & 6.361 & 4.108 \\
Stearate acids & 0.678 & 0.459 \\
Oleat acids & 16.704 & 12.843 \\
Linoleat acids & 0.084 & 0.075
\end{tabular}

Noted:

$A=$ Protein hydrolyzate using papain enzyme

$\mathrm{B}=$ Protein hydrolyzate using L. plantarum bacteria

Table 4: The results of the organoleptic test values for the protein hydrolyzate powder of rebon shrimp.

\begin{tabular}{|c|c|c|c|c|c|}
\hline \multirow{2}{*}{ Treatment (\%) } & \multirow{2}{*}{ Panelist } & Taste & Odor & Appearance & Textur \\
\hline & & Value & Value & Value & Value \\
\hline 6 & 80 & $5.5 \pm 0.2$ & $5.2 \pm 0.3$ & $5.0 \pm 0.2$ & $6.4 \pm 0.2$ \\
\hline 7 & 80 & $6.5 \pm 0.2$ & $6.0 \pm 0.2$ & $6.4 \pm 0.3$ & $6.8 \pm 0.2$ \\
\hline 8 & 80 & $7.0 \pm 0.2$ & $6.5 \pm 0.3$ & $7.3 \pm 0.2$ & $6.6 \pm 0.1$ \\
\hline 9 & 80 & $8.6 \pm 0.1$ & $8.4 \pm 0.1$ & $8.8 \pm 0.2$ & $8.5 \pm 0.1$ \\
\hline
\end{tabular}

Table 5: Characteristics of rebon shrimp protein hydrolyzate added with gum arabic and dextrin binder.

\begin{tabular}{|c|c|c|c|c|}
\hline \multirow{2}{*}{ concentrations (\%) } & \multicolumn{4}{|l|}{ Parameters } \\
\hline & Appearance & Odor & Texture & Taste \\
\hline 6 & Dull yellow color & Shrimp & Dry and smooth & A little savory \\
\hline 7 & A slightly faded yellowish color & Shrimp & Dry and smooth & It's a little tasty \\
\hline 8 & Yellowish white color slightly faded & Shrimp & Dry and smooth & Tasteful \\
\hline 9 & Bright yellowish white color & Strong shrimp & Dry and smooth & Very Tasty \\
\hline
\end{tabular}


Table 6: Degree of brightness of Protein Powder.

\begin{tabular}{|ccc|}
\hline Concentrations (\%) & $\begin{array}{c}\text { Degree of Brightness } \\
(\%)\end{array}$ & Average (\%) \\
\hline & 49.17 & \\
6 & 50.51 & $50.07 \pm 0.77$ \\
& 50.52 & \\
& 8498 & \\
& 85.10 & $85.10 \pm 0.12$ \\
7 & 85.22 & \\
& 90.27 & $90.86 \pm 0.81$ \\
& 91.78 & \\
8 & 90.53 & $97.82 \pm 0.37$ \\
\end{tabular}

color and appearance of the product. Based on ${ }^{17}$, the whiteness or brightness of food products in the form of flour is $87 \%$.

According to $^{18}$, that the degree of whiteness or brightness is influenced by several factors, including the presence of a number of phenol compounds and the activity of phenolase or polyphenol oxidase enzymes, and the presence of amino acid content, which in number affects the mailard reaction which significantly affects the whiteness or brightness.

\section{CONCLUSION}

The $9 \%$ concentration of rebon shrimp protein hydrolyzate can be used as a protein powder as a nutritional supplement with the addition of gum arabic and dextrin binder (1: 0.5$)$. Powdered hydrolyzate with a concentration of $9 \%$ has the potential to enrich food nutrition.

\section{ACKNOWLEDGMENT}

Thanks are conveyed to the Riau University for Research and Community Service, which has supported research funding.

\section{REFFERENCES}

1. Sarkar,S., Gupta,S., Variyar,P,S., Sharma,A., Singhai,S., 2012. Irradiation depolymerized guar gum as partial replacement of gum arabic formicro encapsulation of mint oil. Carbohydrate polymers.90:1685-1694.

2. Abadio,F.D.B., Domigues, A.M., Borges, S,V., and Oliveira,V.M. 2004. Physical properties of powdered pineanpple juice effect of malt dextrin concentration and atomization speed. Jurnal of food Engineering. 64:285-287.

3. Suparmi et al., 2019. Production and Caracteritics of Rebon Shrimp (Mysis relicta) Protein Hydrolysate with Different Concentrations of Papain Enzymes, International Journal of Oceans and Oceanography, 13 (1) : 189-198.

4. Torino, M. H. et al., 2012. Antioxidant and antihypertensive properties of liquid and solid state fermented lentils, Food Chemmistry, 136 (2): 1030-1037.
5. Nurjanah, Susesno SH, Hidayat T, Paramudhita PS, Ekawati $Y$, Arifianto TB. 2015. Changes in nutritional compositions of skipjack (Katsuwonus pelamis) due to frying process. International Food Research Journal. 22(5): 2093-2102.

6. Simanjorang, E., Kurniawati, N., dan Hasan, Z., 2012. Pengaruh pengunaan enzim papain dengan konsentrasi berbeda terhadap karakteristik kecap Tutut, J. Perikanan dan Kelautan, 3 (4) : 209-220.

7. Venugopal, V., 2010. Seafood proteins : Fungtional and protein supplemets in Marine products for Healthcare : Fungsional and bioactive Nutraceutical Compounds from the Ocean ( ed.K.W. Gate ). Boca Raton, FL:Taylor and Francis.

8. Nurjanah, Nurhayati T, Hidayat T, Ameliawati M. 2019Profile of macro-micro mineral and carotenoids in pomacea canaliculata. Current Research in Nutrition and Food Science, 7(1), pp. 287-294.

9. Anggo, D. A., Swastawati, F., Ma'ruf, F. W., dan Rianingsih, L., 2014. Mutu organoleptik dan kimiawi terasi udang rebon dengan kadar garam berbeda dan lama fermentasi. Jurnal Pengolahan Hasil Perikanan Indonesia. 17 (1):53-59.

10. Armenta,R., Valentine, M.2013. Single-Cell Oils as a Source of Omega-3 Fatty Acids An Overview of Recent Advances. Fermentation and Metabolic Engineering Group, Ocean Nutrition Canada Limited, 101 Research Drive Dartmouth. Canada (167-179).

11. Dewita, Syahrul, Hidayat T, Sukmiwati M. 2020. Blending of chorella patin and microalga fish oils as an associated Chorella as potential health food. Pharmacognosy Journal. 12(6): 1346-1350.

12. Ngginak, J., Semangun, H., Mangimbulude, C. J., dan Rondonuwu, S. F., 2013. Komponen Senyawa Aktif pada Udang Serta Aplikasinya dalam Pangan, Sains Medika, 5 (2) : 128-145.

13. Asikin An, Kusmumaningrum I, Hidayat T. 2019, Effect of knife-fish bone powder addition on underexposed characteristics of starch and seaweed kerupuk as calcium and crude fiber sources. Current Research in Nutrition and Food Science, 7(2), pp. 584-599.

14. Jinap, S.llyanur, A, R., Tang, S, C., Hajeb, P., Sharim, K., Khairunnisak ,M.,2010.Sensory attributes of dishes containing shrimp paste with different concentration of glutamate and 5'-nucleotides. Appetite 55:238-244.

15. Schweigert, B. S., Kraybill, H. R., dan Greenwood, D. A., 2011. Amino acids composition of fresh and cooked beef cuts, J. Science Food and Nutrition, 56 (2) :156-162.

16. Winarno, F. G., 2008. Kimia Pangan dan Gizi. PT. Gramedia Utama, Jakarta.

17. [BSN] Badan Standardisasi Nasional. 2011. Tepung Mocaf. SNI 7622. Jakarta : badan Standardisasi Nasional.

18. Hidayat T, Suptijah P, Nurjanah. 2013. Karakterisi tepung buah lindur (Bruguiera gymnorrhiza) sebagai beras analog dengan penambahan sagu dan kitosan. Jurnal Pengolahan Hasil Perikanan Indonesia. 16(3): 268-277. 


\section{GRAPHICAL ABSTRACT}
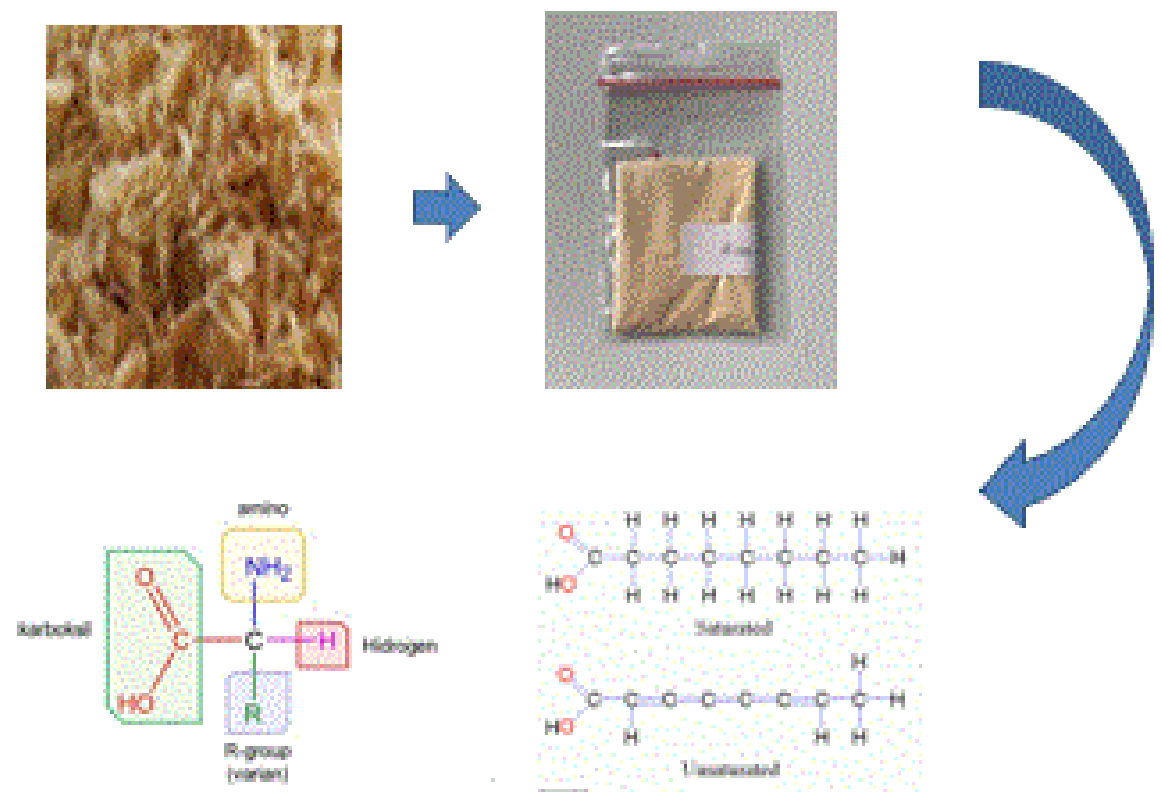

veromet

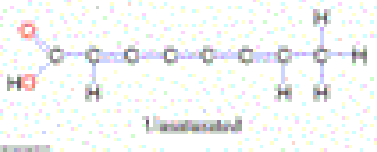

ORGANOLEPTIC EVALUATION

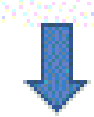

\section{POTENTAL MEMTY FOOD}

\section{ABOUT AUTHORS}

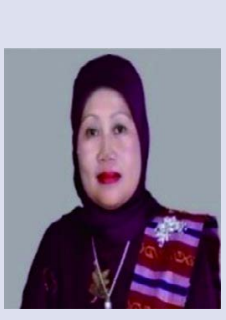

\section{Dr. Ir Suparmi}

Birth: Rumbai, 10-8-1958

e-mail: teten_58@yahoo.co.id

Study :

S1 (Fisheries University of Riau)

S2 (Post Harvest IPB University)

S3 (Marine Biotechnology, University of Riau)

Focus: Fisheries Post Harvest

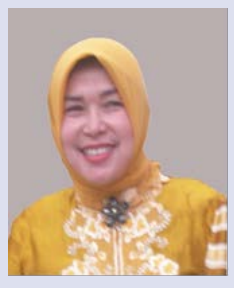

Prof Dr. Dewita MS

Birth : T. Bonai L. Buo, 22-5-1957

e-mail: dewi_58@yahoo.co.id

Pendidikan :

S1 (Fisheries University of Riau)

S2 (Post Harvest IPB University)

S3 (Agricultural Sciences University of Hasanudin )

Bidang: Handling Fisheries and Formulation 


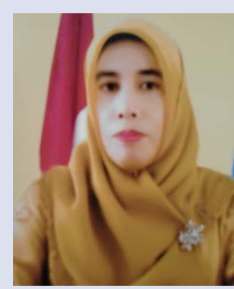

Birth : P. Pengaraian, 16/02/1972

e-mail: hasasali@yahoo.com

Study :

S1 (Fisherise Universty of Riau)

S2 (Food Tech, UKM Malaysia)

S3 (Food Tech, UKM Malaysia)

Focus : Food Technology

Taufik Hidayat MSc, is the engineer of the Agency for the Assessment and Application of Technology working in the field of Fishery Product Processing. At the time of writing, Taufik Hidayat was one of the founders and commissioners of Seaweed House, a technology-based industrial company. It has a strong relationship in the world of fisheries processing. He was once the strong coastal village study team of the Ministry of Maritime Affairs and Fisheries. At present, he is Deputy Secretary General of the Indonesian Fisheries Product Processing Society (MPHPI).

After completing his Master of Science at Bogor Agricultural University, he did a lot of research and teaching in the field of raw materials for aquatic products, especially seaweed. He has also written 6 books, 53 national and international reputable articles, and 5 newspaper articles published by Padang Ekspress. In addition, he is also an editor and reviewer in several scientific journals. He can be contacted via email: taufik.hidayat@bppt.go.id

Cite this article: Suparmi, Dewita, Desmelati, Hidayat T. Study of the Making of Hydrolizate Protein Powder of Rebon Shrimp as a Food Nutrition Enhancement Ingredient. Pharmacogn J. 2021;13(5): 1180-1185. 